\title{
Operating Room to Bench for Gastric Cancer
}

\author{
Han-Kwang Yang \\ Department of Surgery, Seoul National University College of Medicine and Gastric Cancer Center, \\ Seoul National University Cancer Hospital, Seoul, Korea
}

\section{Key Words}

Gastrectomy · Hydrogels · Familial gastric cancer •

Genome-wide analysis

\begin{abstract}
Gastric cancer is the most common cancer in Korea, with an age-standardized rate of 61.2 in males and 23.9 in females (in 2007), one of the highest in the world. Using a large gastric tissue depository and the extensive clinical experience gained from gastric cancer surgery, we work as a 'translational researcher' to apply basic research tools and results to the clinical field. We are also interested in providing answers to the questions in the operating room using the methods of basic research. I would like to introduce our research activities in this review paper.

Copyright $\odot 2011$ S. Karger AG, Basel
\end{abstract}

Gastric cancer is the most common cancer in Korea, with an age-standardized rate of 61.2 in males and 23.9 in females (in 2007), one of the highest in the world [1]. Although treatment results are improving in Korea, mainly thanks to a government cancer screening program, many of our gastric cancer patients still die every year. With more than 800 cases annually and using a large gastric tissue depository and the extensive clinical experience gained from gastric cancer surgery, we work as a 'translational researcher' to apply basic research tools and results to the clinical field. We are also interested in providing answers to the questions in the operating room using the methods of basic research. I would like to introduce our research activities in this review paper.

\section{Dissemination of Cancer Cells during Gastric Cancer Surgery}

Radical gastrectomy with extended lymph node dissection is considered to be the principal treatment for gastric cancer. Traditionally, gastric cancer surgery has been focused on how much perigastric lymph node dissection is performed [2]. Gastric cancer cells spread by direct seeding via infiltration through the gastric wall, via blood vessels and via perigastric lymphatic channels [3-5].

Peritoneal recurrence is thought to be caused by penetration of the gastric wall by the tumor and dissemination of cancer cells from the lymph nodes. However, peritoneal recurrence has been reported even in T1 (tumor invades lamina propia or submucosa) and N0 (no regional lymph nodes involved) cases [6-9]. During radical gastrectomy for cancer, the surgeon opens the gastric lumen

\section{KARGER}

Fax +4161306 1234

E-Mail karger@karger.ch

www.karger.com (c) 2011 S. Karger AG, Basel

$1015-2008 / 11 / 0786-0320 \$ 38.00 / 0$

Accessible online at:

www.karger.com/pat
Han-Kwang Yang, MD, PhD, FACS

Department of Surgery, Seoul National University College of Medicine

Gastric Cancer Center, Seoul National University Cancer Hospital

Seoul 110-774 (Korea)

Tel. +82 22072 3797, E-Mail hkyang@snu.ac.kr 
for resection and anastomosis. If cancer cells detach from the primary site into the lumen, these contaminated gastric contents can be a source of dissemination into the peritoneal cavity. In addition, if lymph nodes are invaded by cancer cells, the inadequate closure of lymphatic vessels during dissection can result in cancer cell spillage into the peritoneal cavity.

Therefore, we hypothesized that during radical gastric cancer surgery, cancer cells from the gastric lumen and from the lymphovascular vessels can be sources of peritoneal seeding. In our study, intragastric cancer cell positivity increased by stage as well as by surgical maneuver. Five out of 38 patients (13.2\%) converted from negative intragastric cytology to positive cytology during the operation. Additionally, about half of the T3 (tumor penetrates serosa without invasion of adjacent structures) patients showed intragastric cytology positivity at the moment of resection, although we had manipulated the stomach gently during dissection. Interestingly, free cancer cells from intragastric fluid were even found in the patients with $\mathrm{T} 1$ gastric cancer. These results suggest that manipulation of the stomach with gastric cancer can increase the detachment of tumor cells into the gastric lumen, that these cells can spread into the peritoneal cavity when the lumen of the stomach is opened during the operation, and that the free cancer cells in the gastric lumen can be the source of peritoneal recurrence even in serosa-noninfiltrating node-negative gastric cancer patients [10]. We analyzed cancer cells by CEA RT-PCR in an ex vivo surgical specimen study, using clipped versus opened lymphovascular pedicles. The differences of CEA mRNA amplification were more evident when lymphovascular pedicles in the specimen were closed rather than when they were opened. The CEA mRNA levels of 7 of 14 patients (50\%) also increased more than twice after the lymphovascular vessels were opened compared to the sealed channels. In this report, using an ex vivo specimen, we clearly demonstrated that cancer cells spill out from the lymphovascular channels [10].

We demonstrated that not only the extent of lymph node dissection but also how to do it is important in gastric cancer surgery. Our model simulated intraperitoneal cancer cell leakage, and provided scientific evidence, according to the principles of oncological surgery, that lymphovascular structures should be well-controlled to prevent cancer cell spillage during surgery. We emphasized that during radical gastric cancer surgery, lymphovascular vessels should be carefully secured either with clips or energy-based devices to avoid cancer cell spillage, which can result in peritoneal seeding. These results also rec-

Operating Room to Bench for Gastric Cancer ommend not performing a dissection with sharp scissors or scalpel, which would open lymphovascular vessels during dissection. In addition, previous studies reported that extensive intraoperative peritoneal lavage can be a useful prophylactic strategy for peritoneal recurrence in patients with gastric cancer [11-13].

\section{Implication of Serum Gastrin Level after Proximal Gastrectomy}

Gastrin is a gastrointestinal hormone, produced by $\mathrm{G}$ cells in the gastric antrum, which stimulates acid secretion from parietal cells. Gastrin is also a growth factor of cancerous and normal cells of the gastrointestinal tract. Gastrointestinal hormones regulate gastrointestinal homeostasis by affecting cell proliferation, differentiation, apoptosis and gene expression [14]. Moreover, elevated plasma gastrin concentrations are associated with increased parietal cell mass and hyperplasia of histamineproducing ECL cells [15-17]. The biological action of gastrin is mediated by its receptor, gastrin/CCK-B receptor [18]. Gastrin/CCK-B receptor has been reported to be present on the surface of human colonic, pancreatic and gastric cancer cell lines [19-21]. An epidemiological study demonstrated that above-normal gastrin levels are associated with an increased risk of colorectal malignancy [22].

We investigated the expression profiles of gastrin and gastrin/CCK-B receptor in human gastric carcinoma tissues and examined their prognostic significance. We reported the gastrin expression rate in gastric cancer was $47.7 \%(133 / 279)$ and the gastrin receptor expression rate was $56.5 \%$ (158/279). Gastrin expression was significantly higher in differentiated gastric adenocarcinoma than in the undifferentiated type (55.1 vs. $43.0 \%$ ), as was the gastrin receptor expression rate (72.9 vs. $46.5 \%)$ which was also significantly higher in the intestinal type than in the diffuse type (75.2 vs. $42.9 \%$ ). Gastrin and gastrin/CCK-B receptor expressions in themselves were not found to be significant prognostic factors. There was an association between gastrin and gastrin receptor expression. We also found that patients with diffuse-type gastric carcinoma tissues expressing both gastrin and gastrin receptor had a poorer prognosis than those who were negative for both, which suggests that gastrin acts as an autocrine growth factor in a subgroup of gastric carcinomas [23]. In addition, after a proximal gastrectomy for gastric cancer, antral gastrin secretion was increased because the target parietal cell mass was lost in these patients (fig. 1). Actually, 

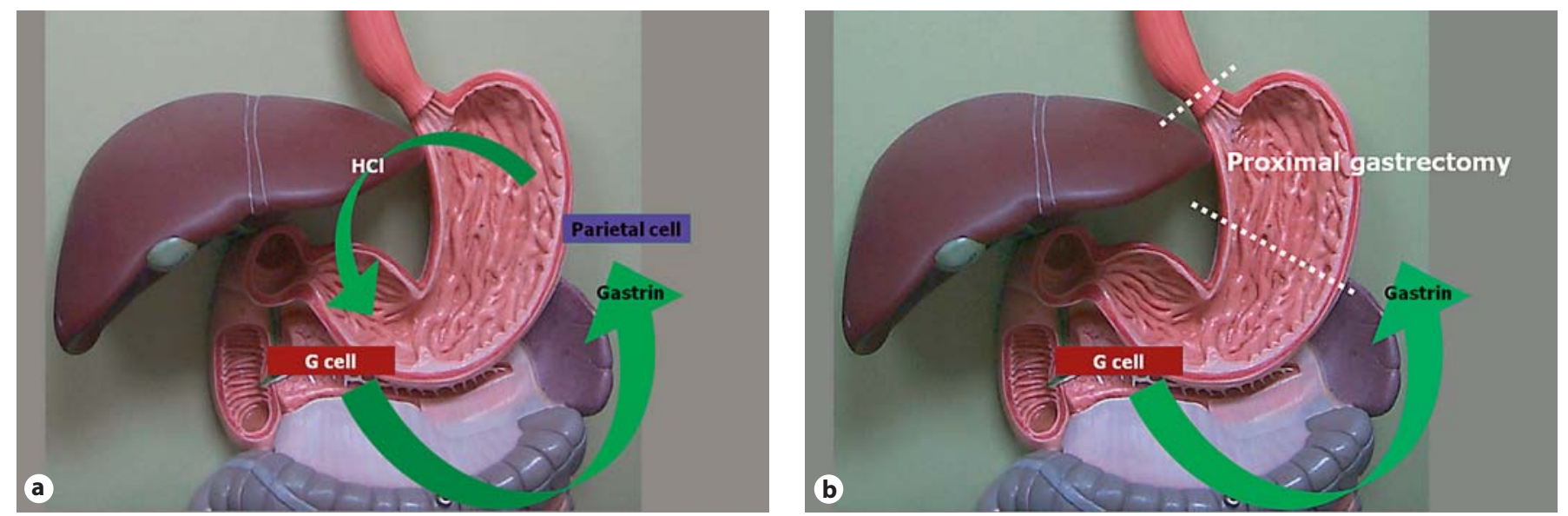

Fig. 1. a, b After proximal gastrectomy and losing parietal cell mass, serum gastrin level can be increased.

in half of proximal gastrectomy patients the serum gastrin level was increased, which may have enhanced the growth of residual gastric cancer cells because with gastric cancer these cells may also have some gastrin receptor (about $50 \%$ ). This finding provides a molecular biological basis for performing proximal gastrectomy only for early gastric cancer in the upper third of the stomach [24].

\section{Exploring the Local Drug Delivery System for Gastric Cancer}

Peritoneal dissemination in patients with cancer recurrence or far-advanced cancer is known to be an intractable problem. Many efforts have been made to develop treatments for peritoneal carcinomatosis, including systemic and intraperitoneal chemotherapy, peritonectomy and thermotherapy. However, systemic chemotherapy is known to be ineffective in peritoneal carcinomatosis patients because drugs do not attain effective concentrations in the peritoneal cavity. Intraperitoneal chemotherapy may result in complications because chemotherapeutic agents are transiently present in high doses.

Thermosensitive hydrogels have gained increasing attention in the field of controlled drug release, to meet the need for prolonged and better control of drug administration, based on their intelligent and reversible behavior in response to temperature variation [25-27]. Reverse thermal gelation of biodegradable polymers has been reported [28-32]. The polymers are liquid in the sol phase at low temperature, but they gel rapidly at $-25^{\circ} \mathrm{C}$. The cold sol phase containing drugs can form a gel and act as a depot for the sustained release of drugs in situ, thereby allowing preferential accumulation of the drug at the injection site. These biodegradable, thermally reversible polymers have potential applications in targeted drug delivery, especially in delivering anticancer drugs to tumor sites [33-35]. Furthermore, targeted drug delivery using biodegradable polymers offers improved efficacy, minimal side effects, and low toxicity to other organs [36-38].

In a previous study, we reported that a thermosensitive hydrogel containing doxorubicin effectively permitted drug delivery into a tumor site and suppressed tumor growth [39].

Considering the potential benefit of thermosensitive hydrogels to deliver high-concentration drugs without systemic toxicity, we tested the idea that this hydrogel system could be applied to treat peritoneal carcinomas. In a mouse model, we showed that a hydrogel combined with paclitaxel was a more effective treatment for peritoneal carcinomatosis than PBS or the hydrogel alone (the bioluminescence method using a luciferase-transfected gastric cancer cell line). A paclitaxel solution had a similar antitumor effect, but such treatment was associated with significant side effects, which were absent when the drug was mixed with a hydrogel. In addition, the dose of paclitaxel $(15 \mathrm{mg} / \mathrm{kg})$ in the hydrogel was half of that for animals treated with paclitaxel solution $(30 \mathrm{mg} / \mathrm{kg})$ only. We demonstrated that a thermosensitive controlled-release hydrogel system can be used to treat carcinomatosis in a peritoneal dissemination mouse model with minimal side effects. A polymeric hydrogel mixed with an anticancer drug may be a safe and effective treatment modality for patients with peritoneal carcinomatosis [40]. 


\section{Familial Gastric Cancer}

Even though it has been reported that $\mathrm{CDH} 1$ is related to diffuse-type familial gastric cancer, no genetic mutation has yet been found in Korea. A patient with familial gastric cancer (FGC) was shown to harbor a germline mutation in the TP53 gene, which encodes p53 and has been previously associated with Li-Fraumeni syndrome. To determine whether mutations in TP53 are associated with FGC in Asians, we screened the entire coding region of TP53 in probands from 23 Korean FGC families. We identified a nonsense (E287X) TP53 germline mutation in a family whose history was compatible with both hereditary diffuse gastric cancer and Li-Fraumeni syndrome. Two members of this family (SNU-G2) were afflicted with brain tumors, 7 with gastric cancers, 2 with sarcomas and 1 with both gastric cancer and a sarcoma. The E287X TP53 mutation segregated with the cancer phenotype in the family members [41]. Another Korean family with the germline c-Met mutation has been reported [42]. Although quite a high number of families meet the criteria for FGC, no CDH1 germline mutation has been reported in Korea or Japan.

A family with CDH1(-) (fig. 2) had a very strong familial history of gastric cancer, but there was no CDH1 or p53 mutation [43]. I operated on a member of this family 10 years ago. Although family members were followed by gastroscopic examination, one of the family members was recently diagnosed with gastric cancer already in stage IV. With limited family members and limited tissue availability, we could not do any classic linkage analysis except to look at the $\mathrm{CDH} 1$ or p53 germline mutation (both were negative). But now we can perform whole-genome sequencing and the most updated bioinformatic techniques on these family members. We will report the result shortly.

\section{Carcinogenesis of Gastric Cancer (Epigenetic Regulation, microRNAs and cDNA Microarray)}

We utilized a large volume of gastric cancer tissue from a depository to try to find genetic or epigenetic mechanisms involved in the development of gastric cancer. We identified several RNAs which were up- or downregulated in gastric tumor tissues with a greater tendency to lymphatic metastasis compared to the matched nonlymphatic metastasis gastric cancer using cDNA microarray. In collaboration with Dr. J. Goldenring at Vanderbilt University, Nashville, Tenn., USA, we worked on

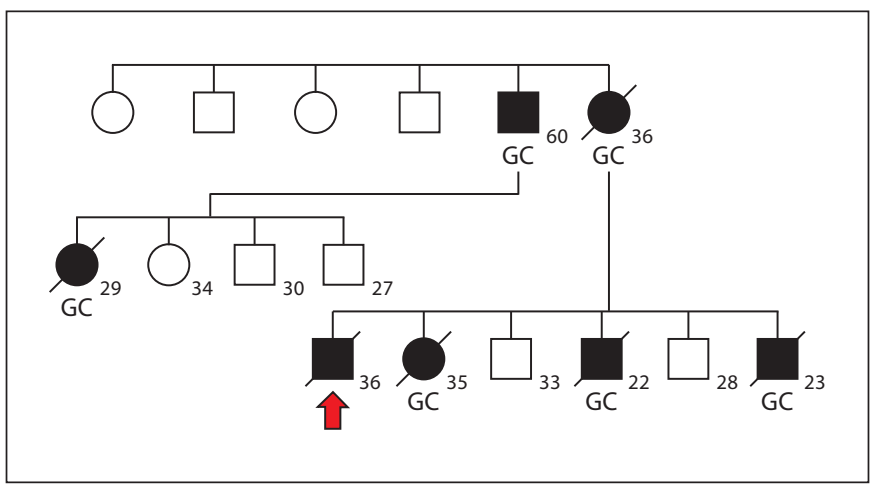

Fig. 2. A family with a strong gastric cancer background but germline $\mathrm{CDH} 1(-)$ mutation.

precancerous lesions such as intestinal metaplasia or spasmolytic-polypeptide-expressing metaplasia for gastric cancer. In the course of this study, we managed to find a good prognosis marker (CDH17) in early gastric cancer [44].

We identified some microRNAs and methylation patterns of the genes which are related to carcinogenesis in gastric cancer, and are now working on animal studies of transgenic mice overexpressing miR-221 in the stomach [45]. We also used the genome-wide research to identify target genes which are related to specific phenotypes. Lymph node metastasis is one of the most important risk factors and the major determinant of the extent of lymphatic dissection in gastric cancer. To identify the genetic markers, we selected some patients from our tissue depository who showed two extreme $\mathrm{T}$ and $\mathrm{N}$ stages; T2N3 (relatively small tumor with many positive metastatic lymph nodes) and T3M0 (bulky and deep tumor with no lymph node metastasis) according to the 6th TNM classification. We extracted RNAs from the tumors and the normal paired frozen-tissue samples, and performed cDNA microarray using the Affymetrix GeneChip Human Genome U133A 2.0 array (Affymetrix Inc., Santa Clara, Calif., USA). We found genes that showed a significantly differential expression between T2N3 and T3N0, and are now conducting a detailed investigation of these candidate genes.

These 'omics' techniques enable the comparison of expression profile and tens of thousands of genes simultaneously, and have a varied applicability in translational research in terms of molecular diagnosis, prognostic prediction and targeted therapy. The microarray gene chip technique was used to identify the genes associated with 
tumor progression including tumor depth, lymph node metastasis and peritoneal seeding [46-48], histological type (e.g. intestinal or diffuse) [49-51] and acquired drug resistance $[52,53]$.

The comparative genomic hybridization (CGH) technique has been used to research the copy number variations of gastric cancer. The copy number alteration of a gene is one of the important mechanisms employed by a cancer cell to regulate the expression of proto-oncogenes and tumor suppressor genes. Genome-wide CGH microarray is a powerful method that can provide a high resolution of information regarding breakpoints of gene copy number changes as well as the functional significance of these changes. Several target genes with copy-numberassociated gene expression changes have been identified by different authors [54-56], and it has also been reported that the cluster pattern of the RNA profile pattern in microarray CGH is significantly correlated with lymph node status and survival rate [57]. Recently, a gene fusion, which is hard to find in solid cancer, was found in gastric cancer by Tao et al. [58] who performed high-density array-based CGH microarrays using 133 gastric cancers (106 primary tumors and 27 cell lines), and identified genomic breakpoints specifically localized to the 5 ' region of the SLC1A2/EAAT2 gene, encoding a high-affinity glutamate transporter in 4 of them. They further analyzed and reported that CD44-SLC1A2 gene fusion most likely causes SLC1A2 transcriptional dysregulation and then establishes a pro-oncogenic metabolic milieu favoring tumor growth and survival.

Serial analysis of gene expression (SAGE) is another powerful technique which enables genome-wide analysis of gene expression in a quantitative manner without prior knowledge of the gene sequences. It can identify genes upregulated or downregulated in tissues and cells of interest, by serial sequencing of about 10-bp-sized multiple tags within a single clone [59]. Yasui et al. [60], the representative researchers of the SAGE method in gastric cancer, generated a total of 137,706 tags (including 38,903 unique tags), which constitutes the largest gastric cancer SAGE library in the world. From the results of SAGE, they also introduced a custom-made array 'Ex-STOMACHIP', containing 395 highly differentially expressed genes, for further research $[60,61]$. From the SAGE results, they could also identify some important genes such as HMGB1 (amphoterin), which is related to invasion and metastasis, and later the potential serum marker olfactomedin 4 and Reg IV [62].

Genetic polymorphism is an important determinant in carcinogenesis. Polymorphisms of genes whose ex- pression is highly altered in cancer can be related to individual cancer susceptibility and could also be a target of therapy. The majority of genetic variation in humans is believed to be due to single-nucleotide polymorphisms (SNPs). Because most cancer develops not by mutation of a single gene but has multifactorial and polygenic causes, genome-wide association study (GWAS) has been introduced to overcome the limitation of linkage analysis that is suitable for monogenic 'Mendelian' diseases [63, 64]. One of the essential elements of a GWAS is the provision of comprehensive information on common variations of human DNA sequences by the database. Since the human genome project started, much information about SNPs has been accumulated and made available $[65,66]$, and the International HapMap Project [67] and the $1000 \mathrm{Ge}-$ nomes Project are in progress (http://www.1000genomes. org/). Regarding gastric cancer, the Japanese GWAS study using the GeMDBJ database (genome medicine database of Japan) is the most representative [68]. It was first started by a group led by Yusuke Nakamura at RIKEN (Institute of Physical and Chemical Research) and the Institute of Medical Science, University of Tokyo, who started a systematic resequencing of genomic DNA of Japanese individuals and constructed the JSNP database in 2002. Following RIKEN's successes, a JSNP-based GWAS was continued as a part of the Millennium Genome Project organized by the Japanese government [69]. One of the successes of the study was to find a common missense SNP (Met1Thr/rs2294008) in exon 1 of the PSCA gene, which is strongly associated with gastric cancer [70]. The PSCA gene has been validated not only in Japan [71], but also in the Korean population [70], in China $[72,73]$ and in Caucasian populations [74-76].

The next generation of sequencing, including RNAseq, is a promising revolutionary tool for transcriptomics [77]. While the microarray technique relies on existing knowledge about genome sequence and high background levels owing to cross-hybridization, the RNA-seq method can catalogue all species of transcript including mRNAs, noncoding RNAs and small RNAs. Because RNA-seq uses high-throughput sequencing instead of Sanger sequencing, it can provide a great amount of information about genes in the resolution of a single base at a relatively low cost. The cost is expected to decrease further, and it may yet enable the whole transcript sequencing of every gastric cancer tissue of interest and facilitate the molecular study of gastric cancer. 


\section{References}

>1 Jung KW, Park S, Kong HJ, Won YJ, Boo YK, Shin HR, Park EC, Lee JS: Cancer statistics in Korea: incidence, mortality and survival in 2006-2007. J Korean Med Sci 2010;25: 1113-1121.

-2 Yoon SS, Yang HK: Lymphadenectomy for gastric adenocarcinoma: should west meet east? Oncologist 2009; 14:871-882.

-3 Iriyama K, Miki C, Kitagawa T: Influence of tumour penetration on period of death after gastric cancer surgery. Br J Surg 1997;84: 866-867.

$>4$ Noguchi Y: Blood vessel invasion in gastric carcinoma. Surgery 1990;107:140-148.

$\checkmark 5$ Ikeguchi M, Katano K, Oka A, Tsujitani S, Maeta M, Kaibara N: Relationship between hematogenic metastasis of gastric cancer and the maximum extent of venous invasion by cancer cells in the gastric wall. Hepatogastroenterology 1995;42:660-665.

-6 Schwarz RE, Zagala-Nevarez K: Recurrence patterns after radical gastrectomy for gastric cancer: prognostic factors and implications for postoperative adjuvant therapy. Ann Surg Oncol 2002;9:394-400.

7 Roviello F, Marrelli D, de Manzoni G, Morgagni P, Di Leo A, Saragoni L, De Stefano A, Italian Research Group for Gastric Cancer: Prospective study of peritoneal recurrence after curative surgery for gastric cancer. Br J Surg 2003;90:1113-1119.

$>8$ Lee HJ, Kim YH, Kim WH, Lee KU, Choe KJ, Kim JP, Yang HK: Clinicopathological analysis for recurrence of early gastric cancer. Jpn J Clin Oncol 2003;33:209-214.

$>9$ Ichiyoshi Y, Toda T, Minamisono Y, Nagasaki S, Yakeishi Y, Sugimachi K: Recurrence in early gastric cancer. Surgery 1990;107:489-495.

10 Han TS, Kong SH, Lee HJ, Ahn HS, Hur K, Yu J, Kim WH, Yang HK: Dissemination of free cancer cells from the gastric lumen and from perigastric lymphovascular pedicles during radical gastric cancer surgery. Ann Surg Oncol 2011, DOI: 10.1245/s10434-0111620-1628.

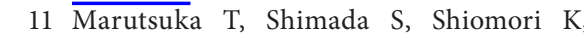
Hayashi N, Yagi Y, Yamane T, Ogawa M: Mechanisms of peritoneal metastasis after operation for non-serosa-invasive gastric carcinoma: an ultrarapid detection system for intraperitoneal free cancer cells and a prophylactic strategy for peritoneal metastasis. Clin Cancer Res 2003;9:678-685.

-12 Shimada S, Tanaka E, Marutsuka T, Honmyo U, Tokunaga H, Yagi Y, Aoki N, Ogawa $\mathrm{M}$ : Extensive intraoperative peritoneal lavage and chemotherapy for gastric cancer patients with peritoneal free cancer cells. Gastric Cancer 2002;5:168-172.

- 13 Kuramoto M, Shimada S, Ikeshima S, Matsuo A, Yagi Y, Matsuda M, Yonemura Y, Baba $\mathrm{H}$ : Extensive intraoperative peritoneal lavage as a standard prophylactic strategy for peritoneal recurrence in patients with gastric carcinoma. Ann Surg 2009;250:242-246.
14 Guo YS, Townsend CM Jr: Roles of gastrointestinal hormones in pancreatic cancer. J Hepatobiliary Pancreat Surg 2000;7:276285.

15 Larsson H, Carlsson E, Mattsson H, Lundell L, Sundler F, Sundell G, Wallmark B, Watanabe T, Håkanson R: Plasma gastrin and gastric enterochromaffinlike cell activation and proliferation. Studies with omeprazole and ranitidine in intact and antrectomized rats. Gastroenterology 1986;90:391-399.

16 Pisegna JR, Norton JA, Slimak GG, Metz DC, Maton PN, Gardner JD, Jensen RT: Effects of curative gastrinoma resection on gastric secretory function and antisecretory drug requirement in the Zollinger-Ellison syndrome. Gastroenterology 1992;102:767778.

17 Bordi C, D’Adda T, Azzoni C, Pilato FP, Caruana P: Hypergastrinemia and gastric enterochromaffin-like cells. Am J Surg Pathol 1995;19(suppl 1):S8-S19.

18 Nakajima T, Konda Y, Izumi Y, Kanai M, Hayashi N, Chiba T, Takeuchi T: Gastrin stimulates the growth of gastric pit cell precursors by inducing its own receptors. Am J Physiol Gastrointest Liver Physiol 2002; 282:G359-G366.

19 Smith JP, Liu G, Soundararajan V, McLaughlin PJ, Zagon IS: Identification and characterization of CCK-B/gastrin receptors in human pancreatic cancer cell lines. Am J Physiol 1994;266:R277-R283.

20 Watson S, Durrant L, Morris D: Gastrin: growth enhancing effects on human gastric and colonic tumour cells. Br J Cancer 1989; 59:554-558.

21 Weinstock J, Baldwin GS: Binding of gastrin(17) to human gastric carcinoma cell lines. Cancer Res 1988;48:932-937.

22 Thorburn CM, Friedman GD, Dickinson CJ, Vogelman JH, Orentreich N, Parsonnet J: Gastrin and colorectal cancer: a prospective study. Gastroenterology 1998;115:275-280.

23 Hur K, Kwak MK, Lee HJ, Park DJ, Lee HK, Lee HS, Kim WH, Michaeli D, Yang HK: Expression of gastrin and its receptor in human gastric cancer tissues. J Cancer Res Clin Oncol 2006;132:85-91.

24 Lee HK, Lee HJ, Hur K, Lee HS, Kim WH, Michaeli D, Choe KJ, Yang HK: Growth effect of gastrin on gastric cancer and its clinical implications for gastric cancer surgery. Oncol Rep 2005; 14:383-388.

25 Ramanan RMK, Chellamuthu P, Tang L, Nguyen KT: Development of a temperaturesensitive composite hydrogel for drug delivery applications. Biotechnol Prog 2006;22: $118-125$.

26 Couffin-Hoarau AC, Leroux JC: Report on the use of poly(organo-phosphazenes) for the design of stimuli-responsive vesicles. Biomacromolecules 2004;5:2082-2087.
27 Ankareddi I, Brazel CS: Synthesis and characterization of grafted thermosensitive hydrogels for heating activated controlled release. Int J Pharm 2007;336:241-247.

28 Rathi R, Zentner GM, Jeong B: Biodegradable low molecular weight triblock poly(lactideco-glycolide) polyethylene glycol copolymers having reverse thermal gelation properties. US Patent, 2000, No. 6(117)949.

29 Rathi R, Zentner GM: Biodegradable low molecular weight triblock poly(lactide-coglycolide) polyethylene glycol copolymers having reverse thermal gelation properties. US Patent, 1999, No. 6(004)573.

30 Cha Y, Choi YK, Bae YH: Thermosensitive biodegradable polymers based on poly(etherester) block copolymers. US Patent, 1997, No. 5(702)717.

31 Jeong B, Bae YH, Lee DS, Kim SW: Biodegradable block copolymers as injectable drug-delivery systems. Nature 1997;388: 860-862.

32 Zentner GM: Biodegradable, thermally reversible gels for drug delivery. The 9 th International Symposium on Recent Advances in Drug Delivery Systems, Salt Lake City, 1999.

33 Zhang J, Misra RD: Magnetic drug-targeting carrier encapsulated with thermosensitive smart polymer: core-shell nanoparticle carrier and drug release response. Acta Biomater 2007;3:838-850.

-34 Rapoport N: Physical stimuli-responsive polymeric micelles for anti-cancer drug delivery. Prog Polym Sci 2007;32:962-990.

35 Choi SW, Kim JH: Design of surface-modified poly(D,L-lactide-co-glycolide) nanoparticles for targeted drug delivery to bone. J Control Release 2007;122:24-30.

36 Bilensoy E, Gürkaynak O, Doğan AL, Hincal AA: Safety and efficacy of amphiphilic $\beta$ cyclodextrin nanoparticles for paclitaxel delivery. Int J Pharm 2008;347:163-170.

37 Pison U, Welte T, Giersig M, Groneberg DA: Nanomedicine for respiratory diseases. Eur J Pharmacol 2006;533:341-350.

>38 John AE, Lukacs NW, Berlin AA, Palecanda A, Bargatze RF, Stoolman LM, Nagy JO: Discovery of a potent nanoparticle P-selectin antagonist with anti-inflammatory effects in allergic airway disease. FASEB J 2003;17: 2296-2298.

39 Kwak MK, Hur K, Yu JE, Han TS, Yanagihara K, Kim WH, Lee SM, Song SC, Yang HK: Suppression of in vivo tumor growth by using a biodegradable thermosensitive hydrogel polymer containing chemotherapeutic agent. Invest New Drugs 2010;28:284290.

40 Yu J, Lee HJ, Hur K, Kwak MK, Han TS, Kim WH, Song SC, Yanagihara K, Yang HK: The antitumor effect of a thermosensitive polymeric hydrogel containing paclitaxel in a peritoneal carcinomatosis model. Invest New Drugs 2010, DOI: 10.1007/s10637-0109499-y. 
-41 Kim IJ, Kang HC, Shin Y, Park HW, Jang SG, Han SY, Lim SK, Lee MR, Chang HJ, Ku JL, Yang HK, Park JG: A TP53-truncating germline mutation (E287X) in a family with characteristics of both hereditary diffuse gastric cancer and Li-Fraumeni syndrome. J Hum Genet 2004;49:591-595.

-42 Kim IJ, Park JH, Kang HC, Shin Y, Lim SB, Ku JL, Yang HK, Lee KU, Park JG: A novel germline mutation in the MET extracellular domain in a Korean patient with the diffuse type of familial gastric cancer. J Med Genet 2003;40:e97.

-43 Humar B, Toro T, Graziano F, Müller H, Dobbie Z, Kwang-Yang H, Eng C, Hampel H, Gilbert D, Winship I, Parry S, Ward R, Findlay M, Christian A, Tucker M, Tucker K, Merriman T, Guilford P: Novel germline $\mathrm{CDH} 1$ mutations in hereditary diffuse gastric cancer families. Hum Mutat 2002; 19 : 518-525.

-44 Lee HJ, Nam KT, Park HS, Kim MA, Lafleur BJ, Aburatani H, Yang HK, Kim WH, Goldenring JR: Gene expression profiling of metaplastic lineages identifies $\mathrm{CDH} 17$ as a prognostic marker in early stage gastric cancer. Gastroenterology 2010;139:213-225.

-45 Kim YK, Yu J, Han TS, Park SY, Namkoong B, Kim DH, Hur K, Yoo MW, Lee HJ, Yang HK, Kim VN: Functional links between clustered microRNAs: suppression of cellcycle inhibitors by microRNA clusters in gastric cancer. Nucleic Acids Res 2009;37: 1672-1681.

-46 Mori M, Mimori K, Yoshikawa Y, Shibuta K, Utsunomiya T, Sadanaga N, Tanaka F, Matsuyama $\mathrm{A}$, Inoue $\mathrm{H}$, Sugimachi $\mathrm{K}$ : Analysis of the gene-expression profile regarding the progression of human gastric carcinoma. Surgery 2002;131:S39-S47.

-47 Wang YY, Ye ZY, Zhao ZS, Tao HQ, Chu YQ: High-level expression of S100A4 correlates with lymph node metastasis and poor prognosis in patients with gastric cancer. Ann Surg Oncol 2010;17:89-97.

-48 Vecchi M, Nuciforo P, Romagnoli S, Confalonieri S, Pellegrini C, Serio G, Quarto M, Capra M, Roviaro GC, Contessini Avesani E, Corsi C, Coggi G, Di Fiore PP, Bosari S: Gene expression analysis of early and advanced gastric cancers. Oncogene 2007;26:42844294.

-49 Hasegawa S, Furukawa Y, Li M, Satoh S, Kato T, Watanabe T, Katagiri T, Tsunoda T, Yamaoka Y, Nakamura Y: Genome-wide analysis of gene expression in intestinal-type gastric cancers using a complementary DNA microarray representing 23,040 genes. Cancer Res 2002;62:7012-7017.

50 Jinawath N, Furukawa Y, Hasegawa S, Li M, Tsunoda T, Satoh S, Yamaguchi T, Imamura $\mathrm{H}$, Inoue $\mathrm{M}$, Shiozaki H, Nakamura Y: Comparison of gene-expression profiles between diffuse-and intestinal-type gastric cancers using a genome-wide cDNA microarray. Oncogene 2004;23:6830-6844.
1 Shah MA, Khanin R, Tang L, Janjigian YY, Klimstra DS, Gerdes H, Kelsen DP: Molecular classification of gastric cancer: a new paradigm. Clin Cancer Res 2011;17:2693-2701.

52 Kang HC, Kim IJ, Park JH, Shin Y, Ku JL, Jung MS, Yoo BC, Kim HK, Park JG: Identification of genes with differential expression in acquired drug-resistant gastric cancer cells using high-density oligonucleotide microarrays. Clin Cancer Res 2004;10:272284.

53 Kim HK, Choi IJ, Kim HS, Kim JH, Kim E, Park IS, Chun JH, Kim IH, Kim IJ, Kang HC, Park JH, Bae JM, Lee JS, Park JG: NA microarray analysis of the correlation between gene expression patterns and acquired resistance to 5-FU/cisplatin in gastric cancer. Biochem Biophys Res Commun 2004;316: 781-789.

54 Tsukamoto Y, Uchida T, Karnan S, Noguchi T, Nguyen LT, Tanigawa M, Takeuchi I, Matsuura K, Hijiya N, Nakada C, Kishida T, Kawahara K, Ito H, Murakami K, Fujioka T, Seto M, Moriyama M: Genome wide analysis of DNA copy number alterations and gene expression in gastric cancer. J Pathol 2008; 216:471-482.

55 Myllykangas S, Junnila S, Kokkola A, Autio $\mathrm{R}$, Scheinin I, Kiviluoto T, KarjalainenLindsberg ML, Hollmén J, Knuutila S, Puolakkainen P, Monni O: Integrated gene copy number and expression microarray analysis of gastric cancer highlights potential target genes. Int J Cancer 2008;15:817-825.

56 Junnila S, Kokkola A, Karjalainen-Lindsberg ML, Puolakkainen P, Monni O: Genome-wide gene copy number and expression analysis of primary gastric tumors and gastric cancer cell lines. BMC Cancer 2010; 10:73.

57 Weiss MM, Kuipers EJ, Postma C, Snijders AM, Siccama I, Pinkel D, Westerga J, Meuwissen SG, Albertson DG, Meijer GA: Genomic profiling of gastric cancer predicts lymph node status and survival. Oncogene 2003;22:1872-1879.

58 Tao J, Deng NT, Ramnarayanan K, Huang B, Oh HK, Leong SH, Lim SS, Tan IB, Ooi CH, Wu J, Lee M, Zhang S, Rha SY, Chung HC, Smoot DT, Ashktorab H, Kon OL, Cacheux V, Yap C, Palanisamy N, Tan P: CD44SLC1A2 gene fusions in gastric cancer. Sci Transl Med 2011;3:77ra30.

59 Velculescu VE, Zhang L, Vogelstein B, Kinzler KW: Serial analysis of gene expression. Science 1995;270:484-487.

60 Yasui W, Oue N, Ito R, Kuraoka K, Nakayama H: Search for new biomarkers of gastric cancer through serial analysis of gene expression and its clinical implications. Cancer Sci 2004;95:385-392.

61 Oue N, Hamai Y, Mitani Y, Matsumura S, Oshimo Y, Aung PP, Kuraoka K, Nakayama $\mathrm{H}$, Yasui W: Gene expression profile of gastric carcinoma. Cancer Res 2004;64:2397.
62 Oue N, Aung PP, Mitani Y, Kuniyasu H, Nakayama $\mathrm{H}$, Yasui $\mathrm{W}$ : Genes involved in invasion and metastasis of gastric cancer identified by array-based hybridization and serial analysis of gene expression. Oncology 2005; 69:17-22.

63 Risch N, Merikangas K: The future of genetic studies of complex human diseases. Science 1996;273:1516-1517.

64 Hirschhorn JN, Daly MJ: Genome-wide association studies for common diseases and complex traits. Nat Rev Genet 2005;6:95108

65 Kruglyak L, Nickerson DA: Variation is the spice of life. Nat Genet 200;27:234-236.

66 Sachidanandam R, Weissman D, Schmidt SC, Kakol JM, Stein LD, Marth G, Sherry S, Mullikin JC, Mortimore BJ, Willey DL, Hunt SE, Cole CG, Coggill PC, Rice CM, Ning Z, Rogers J, Bentley DR, Kwok PY, Mardis ER, Yeh RT, Schultz B, Cook L, Davenport R, Dante M, Fulton L, Hillier L, Waterston RH, McPherson JD, Gilman B, Schaffner S, Van Etten WJ, Reich D, Higgins J, Daly MJ, Blumenstiel B, Baldwin J, Stange-Thomann N, Zody MC, Linton L, Lander ES, Altshuler D, International SNP Map Working Group: A map of human genome sequence variation containing 1.42 million single nucleotide polymorphisms. Nature 2001;409:928-933.

67 The International HapMap Consortium: The International HapMap Project. Nature 2003;426:789-796.

68 Yoshida T, Ono H, Kuchiba A, Saeki N, Sakamoto $\mathrm{H}$ : Genome-wide germline analyses on cancer susceptibility and GeMDBJ database: gastric cancer as an example. Cancer Sci 2010;101:1582-1589.

69 Yoshida T, Yoshimura K: Outline of disease gene hunting approaches in the Millennium Genome Project of Japan. Proc Jpn Acad 2003;79:34-50

70 Study Group of Millennium Genome Project for Cancer, Sakamoto H, Yoshimura K, Saeki N, Katai H, Shimoda T, Matsuno Y, Saito D, Sugimura H, Tanioka F, Kato S, Matsukura N, Matsuda N, Nakamura T, Hyodo I, Nishina T, Yasui W, Hirose H, Hayashi M, Toshiro E, Ohnami S, Sekine A, Sato Y, Totsuka H, Ando M, Takemura R, Takahashi Y, Ohdaira M, Aoki K, Honmyo I, Chiku S, Aoyagi K, Sasaki H, Ohnami S, Yanagihara K, Yoon KA, Kook MC, Lee YS, Park SR, Kim CG, Choi IJ, Yoshida T, Nakamura Y, Hirohashi S: Genetic variation in PSCA is associated with susceptibility to diffusetype gastric cancer. Nat Genet 2008;40:730740 .

71 Matsuo K, Tajima K, Suzuki T, Kawase T, Watanabe $M$, Shitara K, Misawa K, Ito S, Sawaki A, Muro K, Nakamura T, Yamao K, Yamamura Y, Hamajima N, Hiraki A, Tana$\mathrm{ka} \mathrm{H}$ : Association of prostate stem cell antigen gene polymorphisms with the risk of stomach cancer in Japanese. Int J Cancer 2009;125:1961-1964. 
72 Lu Y, Chen J, Ding Y, Jin G, Wu J, Huang H, Deng B, Hua Z, Zhou Y, Shu Y, Liu P, Hu Z, Shen J, Xu Y, Shen H: Genetic variation of PSCA gene is associated with the risk of both diffuse and intestinal type gastric cancer in a Chinese population. Int J Cancer 2010;127: 2183-2189.

73 Wu C, Wang G, Yang M, Huang L, Yu D, Tan $\mathrm{W}$, Lin D: Two genetic variants in prostate stem cell antigen and gastric cancer susceptibility in a Chinese population. Mol Carcinog 2009;48:1131-1138.
74 Lochhead P, Frank B, Hold GL, Rabkin CS, Ng MT, Vaughan TL, Risch HA, Gammon MD, Lissowska J, Weck MN, Raum E, Müller H, Illig T, Klopp N, Dawson A, McColl KE, Brenner H, Chow WH, El-Omar EM: Genetic variation in the prostate stem cell antigen gene and upper gastrointestinal cancer in white individuals. Gastroenterology 2011; 140:435-441.

75 Sala N, Muñoz X, Travier N, Agudo A, Duell EJ, Moreno V, Overvad K, Tjonneland A, Boutron-Ruault MC, Clavel-Chapelon F, Canzian F, Kaaks R, Boeing H, Meidtner K, Trichopoulos A, Tsiotas K, Zylis D, Vineis P, Panico S, Palli D, Krogh V, Tumino R, Lund E, Bueno-de-Mesquita HB, Numans ME, Peeters PH, Quirós JR, Sánchez MJ, Navarro C, Ardanaz E, Dorronsoro M, Hallmans G, Stenling R, Manjer J, Allen NE, Travis RC, Khaw KT, Jenab M, Offerhaus GJ, Riboli E, González CA: Prostate stem cell antigen gene is associated with diffuse and intestinal gastric cancer in Caucasians: results from the EPIC EURGAST study. Int J Cancer 2011, DOI: $10.1002 / \mathrm{ijc} .26243$.
76 Riboli E, Hunt KJ, Slimani N, Ferrari P, Norat T, Fahey M, Charrondière UR, Hémon B, Casagrande C, Vignat J, Overvad K, Tjønneland A, Clavel-Chapelon F, Thiébaut A Wahrendorf J, Boeing H, Trichopoulos D, Trichopoulou A, Vineis P, Palli D, BuenoDe-Mesquita HB, Peeters PH, Lund E, Engeset $\mathrm{D}$, González CA, Barricarte A, Berglund G, Hallmans G, Day NE, Key TJ, Kaaks R, Saracci R: European Prospective Investigation into Cancer and Nutrition (EPIC): study populations and data collection. Public Health Nutr 2002;5:1113-1124.

77 Wang Z, Gerstein M, Snyder M: RNA-Seq: a revolutionary tool for transcriptomics. Nat Rev Genet 2009;10:57-63. 